\title{
Temas de Legislación Procesal Civil ( $\left.{ }^{(}\right)$
}

\author{
Por el Dr. ERNESTO PERLA VELAOCHAGA (*)
}

\section{PRUEBA INSTRUMENTAL.}

Consiste en el medio probatorio que acredila los hechos controvertidos valiéndose de un documento pre-constituído. La definición puede servir para distinguir la prueba documental de la instrumental. Documento es aquello en que consta por escrito una expresión del pensamiento o relación de un hecho. Puede ser así redactado durante el juicio o por lo menos con posterioridad a la demanda. En cambio la prueba instrumental es exclusivamente una de las formas de representación del pensamiento. (1) que contiene el hecho controvertido, que ha sido constituída antes del juicio. Débese notar que en sentido lato documentos son también fotografías, inscripciones, monumentos, etc. por lo que la pruebs instrumental se toma en sentido estricto. Los demás están sujetos a las reglas de prueba pericial o do inspección ocular, (2) así la prueba instrumental es prueba pre-constituída a favor del que la presenta y contra quien se exhibe. (3).

Importancia.-Esta se deduce će su frecuencia y de su cerácter. La constancia de casi todos los actos importantes tanto de la vida centractual como familiar se conservan en documentos, así como los cctos jurídicos más importantes o vinculados a intereses valiosos. Hory actos de tal naturaleza que requieren necesariamente la prueba instrumental. Hay derechos gue dependen de la existencia de un documento. Pero además tiene un valor excepcional porque teniendo el valor de prueba plena demuestra el hecho controvertido con certeza legal, eficacia y fuerza que proviene de ser un acto emanado de las propias personas litigantes, haber sido constituído precisamente para dejar memoria del hecho y estar al mérgen

(x) Ver Nos. XIX, XX y XXI de la Revista "Derecho".

(*) Catedrático titular de Derecho Civil, $y$ de Derecho Procesal Civil en Ia Facultad de Derecho 7 Ciencias Políticas de la Pontificia Universidad Católica del Perú.

(1) L. Prieto Castro. D. Procesal-T. I - póg. 331.

(2) L. Prielo Castro. D. Procesal-T. I - póg. 331.

(3) Nicci - Comentario del C.P.C. T. II pág. 284. 
de todo prcpósito de acreditar algo distinto de lo que en él se contiene Y así sirve para resguardar el interés privado y la paz social. Es de tal importancia que sin exageración puede afirmarse que los otros medios probatorios sólo existen, porque no todos los actos aparecen por escrito. Por esto sin duda, Bentham la califica de anti-litigiosa.

Clasificación.-Hay varias clasificaciones de la prueba instrumental.

a) En yazón de la persona de que emana. Es la pincipal. Se clasifica en documentos públicos, emanados de funcionario público en el desempeño de sus funciones y documentos privados en los que no interviene por lo menos, en el ejercicio de sus funciones, ningún funcionario. sino sólo personas privadas.

b) Por su solemnidad so clasifican en documentos ad solemnitatem $y$ ad probationem según consiituyan la única forma de reconocer la existercia de un acto jurídico determinado o solo sean prueba de este acto, que se puede arreditar también por cualquier otro medio probatorio.

c) Por su fuerza probatoria es auténtico, aquel que prueba por sí mismo y fehaciente, que permite presumir la existencia de este hecho.

I.-DOCUMENTOS PUBLICOS SU VALOR.-(Arts. 401-402-403-407).-La regla general es la contenida en el art. 401, según el cual los instrumenios públicos otorgados con las formalidades legales producen fe piena respecto a la realidad del acto presenciado por el funcionario que lo extendió o autorizó. - Es de notar:

1c Que es condición para que el documento público merezca fe plena que sea extendido con las formalidades que la ley establece. Esto significa que el juez para otorgarle o negarle valor a una escritura pública - cualquier otro documentos de esta calidad debe previamente examinar Ei reune las condiciones de ley o la omisión de las fees que debe dar el notario sobre la capacidad, libertad y conocimiento de los otorgantes, estas onisiones negarian valor de prueba plena al documento aunque no hubiera sido tachado de nulo. Así la fe plena se refiere a la fidelidad del acto celebrado, mas no necesariamente a la eficacia de dicho acto, el que depende que se haya realizado con la capacidad y demás condiciones exigibles para la validez de los actos. Por otra parte por falta de los requisitos propios puede el documento no valer como público pero sí puede valer como documento privado.

$2^{\circ}$-Que la fe plena que, contiene los documentos públicos se limita a los actos que presenció o autorizó el funcionario. Por lo tanto una escritu. ra pública de compra-venta acreditará que este contrato se celebró, mas nó que se entregó el precio respectivo, si el notario no dejó en la escritura fe de que en su presencia se verificó dicha entrega. Esto es muy de tenerse en cuenta en los certificados que otorgan no los notarios, sino otros funcionarios y que más bien suelen tener el carácter de informes sobre determinados hechos. Debe notarse igualmente que todo lo expresado no impide que se deduzca la simulación del contrato o del acto en general, celebrado ante un funcionario.

Como una consecuencia, el art, 402 otorga a las copias autorizadas: 
por los funcionarios, la misma fe que tienen los originales. Lo único qus se exige é que tales copias sean auténticas, es decir, autorizadas por el funcionario, esto es, copia certificada y no copia simple; que sea una do aquellas copias que se expiden en el ejercicio de facultades legales, tales como las boletas o los testimonios que expiden los notarios; las copias literales y otras que otorgan los Registros Públicos. En cuanto a los primeros, creo, apesar de más autorizada opinión (1) que las boletas y los testimonios merecen igual fe cunque es verdad que las primeras por su caliadad de suscinto resumen dé la escritura sólo acreditarán el contrato o acto celebrado; mientras que los testimonios acreditarán además todas y cada una de las condiciones bajo las cuales se ha celebrado. Así también lo ha establecido la jurisprudencia.

También como consecuencia de la regla general, el crt. 403 dispone que tendrán valor de prueba plena los documentos públicos otorgados en país extranjero con estas condiciones:

$1^{0}$-Que se hrya extendido con sujeción a las leyes del país en que se han hecho. Es la aplicación de la ley locus regit actus. Por ella se impone a los jueces a apreciar esta clase de probanzas de conformidad zon las leyes extranjeras y los partes, comprobar el hecho de que ellas se han cumplido al extender documentos. Este hecho se puede acreditar con la certificación pertinente de los agentes diplomáticos o consulares.

2 - La legalización sirve para autenticar el documento medianta la declaración de cutenticidad de las firmas del funcionario que lo suscribe y de su carúcter de tal.

Los documentos escritos en idioma extranjero deben ser presentados con su respectiva traducción al castellano. Art. 408.- Esie es un principio general de tal manera que se refiere también a los documentos privados. La traducción puede ser presentada por la parte que exhibe el documento. La parte contraria puede aceptar o no la traducción. Sólo en este último caso el juez nombrará un perito traductor. En la práctica se acostumbra obviar estas dificultades presentando, con el documento ariginal, su traducción oficial.

Por último, el crt. 407 también señala una regla sobro la fe del do. cumento público estableciendo que constituye la única forma de probar los actos para los cuales la ley exige como requisito de la existencia del acto un documento de esta calidad.

Esto es que los documentos constituyen una forma do prueba, en algunos casos, de la existencia del acto mismo $y$ entonces se exige el documento ad solemnitatem y otras veces se puede probar el acto valiéndose de cualquier medio probatorio en cuyo caso el documento es sólo ad probationne. Este precepto legal establece el principio de que siempre que la ley exija como solemnidad, es decir como condición para la existencia del acto, el documento público, esta sería la única forma de probar su existencia.

(2) - Romero - Ob. eit. T. П - pág. 511. 
Ya se ha indicado que un documento público que no merece fe plen $\alpha$ por algún defecto formal puede valer como documento privado y mediante el reconocimiento (1) quedar autenticado; esto ha sido admitido por nuestra jurisprudencia.

La fuerza probatoria del documento público está así sujeta a las reglas siguientes:

a) El documento público produce por 'sí fe plena teniéndoze por auténtico, mientras no se pruebe lo contrario. Por lo tanto quien impugna esta autenticidad es quion debe probar contra ella (2). Si la tacha de falsedad se refiere a la copia presentada bastará su comprobación con el original o la presentación de una nueva copia. Si la tacha es relativa al original, debe procederse a deducirla en vía de acción o por vía incidental.

b) Las manifestaciones del funcionario están sujetas a prueba, tal la capacidad de las personas que comparecen ante ellos.

c) Las manilestaciones de las partes igualmente están sujetas a las probanzas que se hagan contra ellas.

d) Los actos realizados ante Notario como entrega de dinero, etc. producen fe plena sobre la realidad del acto.

Nulidad y Falsedad.-Arts. 404, 405, 406.- En el C.P.C. se some. ten a las mismas reglas la nulidad y la falsedad. La diferencia entro ambas es sin embargo clara: la nulidad se refiere a un defecto esencial del documento que lo hace absolutamente ineficaz de tal manera qus no tiene ninguna validez formal. En cambio le falsedad proviene de una discrepancia de lo que aparece en el documento con la realidad, ya sea por alteroción material del documento, probado por borraduras y enmenciaduras al texto original, o intelectual del instrumento ya sea por la alieracićis de la realidad, consignando hecho falsos o actos distintos de los que debían aparecer, así la alteración de cantidades, dar por recibido el precio para simular una donación, eic.

Tales reglas se pueden sintetizar en las siguientes:

1) El documento público produce efectos mientras no se resuelva sobre su ineficacia o sobre su nulidad, salvo aquellos casos en que el vicio sea manifiesto, de conformidad con los artículos 405 del C.P.C.

2) I. nulidad $y$ falsedad se puede plantear do oficio $o$ a pedido de parle:

a) De oficio. Esto puede suceder cuando la nulidad o falsedad es ostensible. Así un documento público que estuviera otorgado por persona incapaz por razón de edad, aquellos contratos que fueran contra el orden píblico o las buenas costumbres, carecen ipso jure de valor. O también las es. crituras públicas que no se encuentren dentro del orden correlativo. (art. 59 y 60 de la L. del N.Y

b) La nulidad o falsedad también so puede deducir a instanci $x$ do

(1) Romero - Ob. cit. T. Il pág. 525 .

(2) Alsina - Ob. cit. T. II - pág. 299 
parte. Esta se puede hacer en dos vías: a) en vía de acción o sea entablandrs juicio orclinario para que se declare la nulidad o falsedad de un documento público o privado total o parcialmente; $\mathrm{y}, \mathrm{b})$ por vía incidental dertro de un juicio ya entablado deduciéndose la falsedad y nuliaad de un documento presentado. Estos incidentes, contra la regla general, suspenden la presecución de lo principal. En ellos se puede usar toda clase de pruebas. La probanza corresponde, si se trata de documento público al que alega la nulidad; $\mathrm{y}$ de documento privado, al que lo ha presentado, pues carece de fe mientras no esté autenticado. Basta en este caso negar el documento para que carezca de valor.

c) La nulidad y falsedad se puede deducir en cualquier momento del juicio. No importa el término transcurrido desde su presentación. Pero segúr. el anieproyecto Cornejo se fija el plazo de 3 días contados desde la admisión del documento para deducir su tacha. Sin embargo que es evidente la necesidad que existe de fijar límites para el ejercicio de este derecho de tacha, evitando así maniobras dilatorias, debe tenerse en consideración que hay documentos cuyos defectos no les permiten que se tengan en cuenta, cualquiera que sea el transcurso del tiempo desde su presentación.

4) La nulidad y falsedad se tramita en cuerda separada. Esta disposición tiene por objeto no interrumpir la secuela de lo principal. Pero no puede producirse sentencia mientras no haya terminado la tramitación del iricidente.

5) La resolución se expide conjuntamente con la sentencia. En esto se establece una excepción, pues los incidentes pueden resolverse por lo general, antes o con la sentencia.

6) La misma tramitación tiene la nulidad y falsedad en Segunda Xinstancia.

\section{II)._DOCUMENTOS PRIVADOS}

La segunda parte de este capitulo del C. de P.C. se refiere a los documentos privados. La definición ha sido dada como aquellos documentos en que no intervienen funcionarios públicos en su carácter de tal.

También adquieren el carácter de tales, los documentos públicos que resultaron inválidos e ineficaces por falta de los requisitos y solemnidades gue la ley les impone.

Se distinguen de los documentos públicos:

1 . Porque los documentos privados no requieren de forma alguna.Art. 410 .

$2^{\circ}$ Por su fuerza probatoria. Los documentos públicos valen por sí mismos y mieniras no se establezca su nulidad o falsedad. En cambio, el mérito del documento privado depende de que pueda ser autenticado y del grado de certeza que produzca su reconocimiento.

$3^{\circ}$ El documento público se emplea para cualquier acto jurídico; mientras que el documento privado no es suficiente para acreditar la existencia de todos los actos jurídicos sin excepción. Para la comprobación de 
la existencia de ciertos actos que se consideran muy importantes o de trascendencia no es suficienie el documento privado.

Como debe entenderse por documento privado en contraposición al público, aquel en que no interviene funcionario público alguno en el ejer. cicio de su cargo, como consecuencia este documento carece de una forma pre-determinada, estableciéndolo así el artículo 410 del C.P.C. al decir que "se fuede redactar en cualquier forma e idioma". Así su calidad no está vinculada a que se firme o no por los otorgantes o testigos ni tampozo a la legalización de la firma.

Pero nuestra ley procesal establece en el art. 411 una regla especial respecto a la firma de documentos que se otorgan en varios ejemplares. Se podría considerar la cuestión en toda su extensión: a) documentos sin firma, tienen valor en cuanto han sido extendidos o mandados extender por otras personas.

b) El documento con sola firma del que lo presenta no tiene valor a su favor, pero puede tenerlo para terceros (1). $\bar{A}$ este respecto la regla del art. 411 según la cual "si el instrumento privado se ha extendido en varios ejemplares, basta que el que tiene en su poder cada uno de los otorgantes, se halle firmado por el otro".

La condición de que se trate de documentos otorgados en varios ejemplares solo se produce en los contratos sinalagmáticos, en los que cada parte tiene interés en acreditar las obligaciones de la otra. Está justificado que no exista la obligación de la firma del que la presenta o exhibe desde que con el mismo acto de la presentación está acreditando que reconoze la efectividad y mérito del documento.

c) El último caso, el documento firmado por todas las partes es la forma que más se conforma con la naturaleza de los contratos, no requiero ninguna aciaración salvo que como loz otros documentos privados deben quedar autenticados.

El mérito del documento privado se adquiere por el reconocimiento y se pierde por la declaración de falsedad o nulidad y por les contra do. cumentos.

Trataremos sucesivamente de estas cuestiones.

El reconocimiento constituye la forma de autenticar un documento mediante la declaración jurada sobre si la firma y el contenido son del que aparece como otorgante del mismo documento, sólo excepcionclmente se pronuncia sobre si la obligación que contiene es exacta.

Constituye así un acto formal sobre los aspectos extrínsecos del docursento no generalmente, sobre la efeciividad del acto que contiene. Ës cierto que un clocumento así reconocido constituye una presunción juris tantum de la existencia de la obligación que aparece en él, pero también que contra ella procede la prueba en contrario.

Personas obligadas al reconocimiento.-Art. 401. Es evidente que el reconocimiento lo puede solicitar toda persona que tenga interés en ello; es sólo la aplicación de principios generales.

(1) Homerc. - Ob. cit. T. II - pág. 571. 
En cuanto a quiénes están obligados a practicarlo, el art. 403, impone esta obligación a toda persona que ha suscrito $u$ otorgado un documento $y$ el art. 420 extiende esta obligación a quien aún sin firmarlo lo ha extendido o hizo extender.

Esto supone que el reconocimiento puede practicarse no sólo por el propio otcrgante sino por su apoderado con poder esencial, por el que firmó $\alpha$ ruego de otro, por los herederos, por los testigos instrumentales, por los representanies legales y los mandatarios judiciales.

ACTUACION DEL RECONOCIMIENTO.-Arts. 416 - $428-429$.

Oportunidad.-Puede ofrecerse y actuarse en cualquier comento del juicio según los artículos 413 y 419.

La forma de su aciuación depende de la persona que debe practicarlo y de las documentos que debe reconocer. Se puede señalar por etapas en esta forma:

$1^{\circ}$ Pedido el reconocimiento, el juez ordenará que el obligado comparezca el día y hora que se le cite (art. 414). Este auto es inapelable según el art. 4l4. El único recurso que cabe es el de oposición que se estudiara oportumamente.

$2^{\circ}$ a) El obligado es indudablemente quien aparece suscribiendo el documento por sí o por otro. Esta diligencia es personal. Sólo puede practicarla el apoderado con poder especial para reconocer, si el que lo ha solicitado consiente en ello (art. 415.- b) El representante legal está obligado a reconocer el documento que suscribió esté o no en el ejercicio del cargo. El reconocimiento se puede hacer por los actuales repiesentantes (ait. 424), esto es por el que ejerce la representación en el moments en que picle el reconocimiento, y en este caso el reconocimiento no sólo versa sobre la autenticidad del documento sino también sobre si es verdadero el hecho o la obligación que contiene. Pero puede obligarse al reconocimiento a los representantes que han cesado en el cargo conforme al ari. 425, en cuyo caso el reconocimiento se apreciará de conformidad con las reglas de la prueba testimonial. El incapaz, apto para el momento del recrnocimiento, está obligado a reconocer el documento que en su nombre firmó su representante (art. 422). - c) El reconocimiento por los mandaterios judiciales, gerentes o administradores de sociedades civiles o comerciales y los jefes o presidentes de personas jurídicas de derecho privado y representantes de derecho público interno (art. 319 C.P.C.) debe practicarse por los que ejercen el cargo en el momento en que debe practicarse la diligencia del reconocimiento o aplicarse las reglas del art. 425 ya comentado. El art. 424 añade que estos reconocimientos se practicarán "conforme a los artículos 416 o 422 según los casos". Esto ha ocasionado críticas encontrándose objeciones el precepto (1). Sin embargo, la solución debe ser esta si lo practican las mismas personas que suscribieron el documento este se efectuaró según el art. 416, refiriéndose solo a la firmc y al contenido; pero si la realizan personas distintas por estar ejerciendc

(1) Romero - Ob. cit. T, II - pág. 589. 
dicho cargo en el momento del reconocimiento, tenàrón que pronunciarse también, scbre la existencia de la obligación que contiene según el art. 422. La objeción de que el nuevo representante, puede ignorar la efectividad de ia obligación, es inadmisible pues debe conocer loclos los asuntos que afecten a su representado.- Cuando la persona jurídica tenga dos representantes que deban ejercer el caigo conjuntamente ambos deberán prac. ticar el reconocimiento.-- d) El reconocimiento por los herederos, en casos de muerie del ccusanie. art. 422. - Este reconocimiento sólo afecta al heredero que lo hace. $\epsilon$ ) Los testigos instrumentales, (art. 423) en los casos de ausencia del otorganie del lugar del juicio o negación de su firma por él o sus herederos.

3) Pueden presentarse tres circunstancias en la actuación del reconocimiento:

a) $\mathrm{E}$ l obligado concurre a la diligencia. Si el obligado concurre a la diligencia esta se practica teniéndose en cuenta la clase de documento de que se trata, siendo las reglas las siguientes:

I) La regla general es la del art. 416 según la cual el reconocimiento ciebe comprender dos declaraciones: si la firma es del que reconoce y si el contenido es el mismo o ha sufrido alteraciones. En este último caso, indicará en qué consisten estas. En cuanto al reconocimiento de la firma, este crea la presunción de la autenlicidad del contenido. Según el art. 430: este conterido se tiene por verdadero mediante su reconocimiento, estableciencio la independización de uno y oto. Pero según el art. 593 del C.P.C. basta el reconocimiento de la firma para que el documento aprreje eje. cución.

Debe notarse realmenle que así el reconocimiento se refiere a la autenticidiad estrínseca del documento; no según el art. 416 a la efectividad de la obligación que contiene. Sólo en los casos especiales del art. 422 se podrá admitir que en una diligencia de reconacimiento haya promunciamiento sobre el valor y la eficacia intrínsecx del documento que es su z:atriz. En lodos los demás casos, estas alegaciones deben ser rechazadas en una diligencia de reconocimiento.

$E_{s}$ de notar que los terceros pueden practicar el reconocimiento en: forma evasiva. Así se desprende del inciso segundo del art. 434 que prescribe el cotejo "cuando las personas indicadas en el art. 427 practican el reccinocimiento en forma evasiva". siendo estas las personas extrañas al juicio.

II) Los documentos con firma legaiizada por notario.-Art. 417. Se practica su reconocimiento omitiendo lo relativo a la suscripción del otorgante. Lo que está justificado desde que con tal legalización ya existe fe pública de su autenticidad. Se ha sostenido (1) que la prohibición na debió ser absoluta, que hay casos como el cle tacha de falsedad, en que debe proceder este reconocimiento. Sin embargo debe notarsé que la lacha:

(1) Romero - Ob. cit, T. II - pág. 590. 
de falsedad de una firma legalizada por notario debe ser probada por quien la aiega, el aparente suscritor, y por lo mismo no cabría la procedencia de un reconocimiento de la firma tachada, en todo caso sólo procedería el cotejo de la firma.

III) Documentos firmados a ruego.-Art. 418.-El reconocimiento se praciica por ambas personas, esto es el rogante y el rogado.

IV) Documentos sin firma.-Art. 427.-Así como facturas, elc. cabe su yeconocimiento pronunciándose el que la reconoce sobre si lo extendió o mandó extender, si hay alteraciones, en qué consisten éstas.

V) Documentos suscritos con facsímiles, iniciales, sellos. - art. 419. Se reconocen pronunciándose el obligado no solo sobre los extremos del art. 416, sino también sobre si puso o mandó poner el sello, inicizles o sello.

VI) Documentos en copia o reproducción fotográfica, la prensa u otros procedimientos semejantes.- Ārt. 427. Se reconocen en la misma forma que los originales. Como lo hace notar muy bien el Dr. Romero en la obra citada, (1) en estos casos hubiera sido más exacto disponer que el obligado al reconocimiento declarara si la copia es igual al original en su contenido y firma. Este procedimiento ha difundido el uso de las copias fotostáticas y no cabe oponerse a que la diligencia de reconocimiento se verifique con las copias que reproducen los documentos originales.

Por razón de las personas la aciuación de la diligencia de recono. cimiento está sujeta a estas regals: I) Si el que lo practica es el propin otorgante o su apoderado o el representante que lo suscribió, debe practi. carse sobre la autenticidad de la firma y del documento (arts. 416 y 424). II) Si se trata de herederos del que aparece suscribiéndolo, art. 424, de sus representantes legales o de los que representan a otros, según los arts. 3 y 19 del C.P.C., corresponde, art. 424, además la declaración sobre si es verdadero el hecho o la obligación que contiene.

b) La segunda posibilidad es que el obligado concurra a la citación, $y$, sin embargo, se niegue a pronunciarse sobre los hechos que comprende el reconocimiento o eluda el reconocimiento con palabras ambiguas o de cualquier otro modo.

En este caso, el art. 428 permite al juez proceder de oficio o a petición de parte, $\alpha$ dar por reconocido el documento. Sin embargo, debe entenderse que esta grave decisión solo cabe en el caso de que seu el propio presunto otorgante quien procede en esa forma $Y$ no cuando por no serlo, Es presumible que efectivamente no pueda pronunciarse sobro la autenticidad del documento o de la obligación que contiene.

c) La tercera circunstancia que puede presentarse es que el citado al reconocimiento no concurra a la citación.

En este caso según los arts. 425 y 427 esto es, sea o no el empla. zado parte on el juicio, debe ser citado nuevamente bajo apercibimiento.

Este apercibimiento varía según se trate $\alpha$ ) de persona que es parto

(1) Romerc - Ob. cit. T. Il - pág. 692. 
en el juicio sieizdo entonces el de dar por reconocido el documento en su contenido y firma; b) si se trata de persona extraña al juicio el apercibimiento consiste en ser conaucida al juzgado por la fuerza pública.

Valor probatorio. - El valor probatorio del documento privado se puede establecer en esta forma: a) Tiene vaior de prueba plena el documento reconocido o dado por reconocido por el propio otorgante, art. 431, y por loz representantes legales del olorgante que actualmente ejercen el cargo.- b) Tiene valor de prueba testimonial, en los casos en que el reconocimiento haya sido hecho por los testigos instrumentales y perzonas que no son parte en el juicis (firma a ruego, reprenentantes que han dejaso de serlo, art. 413)..c) Los documentos puivacos no reconocidos tendrán el valor que les asigne el prudente arbitrio del juez, esto es que los apreciará en relación con las demás probanzas cactuadas. - El valor probatorio del documento expresamente reconorido es indepenciente de la competencia del juez según el art. 432 .

\section{COTEJO.}

Concepto.-Es el medio probatorio que consiste en la comparación de un doclimento auténtico con otro cuya cutenticidad se pretende establecer.

Debe aclararse que el cotejo comprende tanto la comparación del IExto del doaumento como el de las firmas, según lo establece expresamente el artícialo 434.

Procede el cotejo: a) respecto del otorgante: 1) si hace el reconocimiento en sentido negativo esto es, negando su firma o el contenido en el acto judicial del reconocimiento. - 2) crando ha muerto. En este caso se puede recurri- indistintamente al cotejo o al reconocimiento por los herederos, de conformidad con el art. 422 ya estudiado. Aunque tenga herederos declarado: puede optarse por uno u otro medio de catenticar el documento. 3) Si el otorganie está ausente. Puede entenderse la ausencia como estado legal o simplemente como el hecho de no encontrarse el obligado en el lugar del juicio en el momento en que debe practicar el reconocimiento. En el primer caso hay representante que por él puede verificar el reconocimienta, es el curador. Si el documento fue otorgado ya por representante no puede ser éste el caso al que se refiere la ley, desde que el cotejo es medio supletorio de autenticar los documentos cuando el reconocimiento no puede verificarse. La regla se puede sintetizar asi: cuando el otorgante firma y se vuelve inhábil entonces procede el cotejo. 'Cuando el otorgante no firma sino su representante, entonces el cotejo se puede verificar en dos formas: si el representante, sigue en actual ejercicio, el cotejo se verificaría con él de conformidad con el art. 416; si el otorgante ya no está en el ejercicio del cargo entonces el reconocimiento lo puede practicar de conformidad con el artículo 422 pero tendró solamente el mérito de prueba testimonial. Cucindo ol otorgante no firmó el documento pero sanc $y$ es hábil en el momento en que dibe practicarse el reconocimiento este debe hacerse por esta misma persona.

Puede considerarse esto como contradictorio a lo dicho anteriormente respecto a los herederos. Pero debe estimarse que el caso es distinto, 
por cuanto en el de ausencia hay alguien que tiene la representación del obligado lo que no sucede con los herederos que continúan la personalidad de su causante, lo sustituyen pero no lo representan. Así pues el caso es para aquél que ha desaparecido del lugar de su domicilio cuyo paradero se ignora pero no se encuentra en la condición legal de desparecido y cuando fue otorgado por el mismo.

3) Si el obligado es inhábil. En este caso también se refiere al inhábil y no al incapaz declarado así judicialmente para indicar que se trata del obligado al reconocimiento devenido incapaz. Como representante, el curador nombrado posteriormente no ha suscrito el documento no puede reconocerlo, debe recurrirse al cotejo en caso de que el representante actual - anterior, es él el que debe reconocerlo; si no es incapaz es el propio otorgante el que debe practicar esta diligencia.

En cuanto a terceros, procedo el cotejo si realizan el reconocimiento en forma evasiva. Los propios interesados no pueden evadir el reconocimiento porque el apercibimiento es dorlo por reconocido; pero si los terceros $y$ testigos instrumentales porque para ellos no existe tal apremio.

Actuación.-Art. 436. - Señalando por etapas la actuación de la diligencia de cotejo deben indicarse estas: 1) en cuanto a su oportunidad, el cotejo procede en cualquier momento del juicio por ser una modalidad de la prueba instrumental (art. 409). - 2) En el recurso ofreciéndose el cotejo se designará el documento o documentos que han de servir para lo comparación (art. 436). Pero no puede ofrecerse para el cotejo sino documentos auténticos o aquellos que las partes admitan como tales. Por esto es que el art. 437 señala taxativamente los únicos docurmentos que pueden servir de base para el cotejo. Son: a) los que las partes designen de común acuerdo. Es claro que si ofrecido o designado un documento la otr $\alpha$ parte lo admite como auténtico no hay ninguna dificultad para que pueda servir de base para el cotejo. Se trata de una cuestión comprendida dentro de la esfera privada.- b) Las escrituras públicas y documentos protocolizados. Estos ya tienen la calidad de autériticos. Por una cabal interpretación extensiva, todos los documentos públicos puejen servir y son admitidos como base para el cotejo en virtud de este numeral. - c) Las firmas puestas en diligencias y actuaciones judiciales. Sćlo cabe al respecto hacer notar que no se refiere a las firmas puestas en los recursos presentados ante el juez sino en las diligencias actuadas en el propio juzgado, esto es ante el juez y actuario y eventualmente ante las mismas partes y por lo mismo cuya autenticidad está acreditada y controlada. Es por esto que no se refiere a la escriturc, $\sin n$ a las firmas, porque el acta la escribe el actuario. Por lo mismo, no existe el peligro que cree ver el Dr. Romero (1).- d) Las firmas puestas en documentos privados judicialmente reconocidos, pues estos se tienen por auténticos. Se discute sobre si las reglas se refieren también a los documentos dados por reconocidos, estando la doctrina en contra (2). Sin

(1) Romero. Ob. cit. T. II - pág. 624.

(2) Pisanelli-Relaciones del Proyecto C.P. Tecría General de la Prueba. Vol. III-pág. 206. 
embarg(, no existiendo distinción en nuestra legislación sino más bien dándosele el mismo valor a los documentos privados que a los reconocidos, creo que no puede hacerse enire nosotros, ninguna distinción. Pueda suceder que no exista ninguno de estos documentos en cuyo caso según el art. 438 "puecie obligarse a la persona cuya letra o firma es materia del cotejo. a que escriba en presencia del juez las palabras que éste dicte o ponga su firma...". Es de notar el peligro de este procedimiento, pues, ya sea por nerviosismo o por malicia podrá disimularsa la letra hasta tal punto de llevar a error a los peritos.

3) El juez "con contestación o sin ella" dicta un auto comprendiend.) varias resoluciones. Es de notar que este auto aplicando las reglas generales debe dictarse a petición de parte y no de oficio salvo que la prueba se verifique también de oficio o sea a iniciativa del juzgado. En dicho auto, el juez resuelve sobre los documentos para el cotejo, en primer lugar. Este auto es muy importante y es inapelable, pues el juez simplemente tiene que decidir cuales son los documentos que están dentro de los que señyla el art. 437.- En segundo lugar y en el mismo auto el juez designa los perî́os que deben efectuar el cotejo. - art.435 - El cotejo pues se hace por peritos y así es una especie de prueba pericial. Por lo tanto está sujeto a las reglas de esta. En cuanto a la designación de peritos, como no existe profesionalización al respecto se acostumbra nombrar a calígrafos o a notarios para que lo practiquen. Sin embargo, ya existe una técnica que se encuentra divulgada por los miembros de la Policía de Investigaciones. Puede, en teoría nombrarse uno o dos peritos, pero en la prástica siempre se designan dos.- En tercer lugar, el juez desig. na día y hora para que se practique la diligencia - art. 439-en presericia del juez.- 4) El día y hora señalados se realiza la diligencia sentándese acta en que se consigna el parecer de los peritos. Pueden estos solicitar: a) que se tomen ampliaciones fotográficas de las letras o las firmas, que se analicen la calidad de las tintas o se practique otra operación análoga. Art. $440 .-$ b) Pedir plazo para la presentación del dictamen.

5). El dictamen presentado fuera de la diligencia en el Juzgado, se pone en conocimiento de las partes para que éstos aleguen lo converiente.

También puecien presentarse dictómenes con firmas legalizadas, hechos por peritos de parte, ante Notario.

Vaior probatorio.

El dictamen se aprecia según las reglas de la crítica, esto es, que no constituye pruebs plena.

\section{EXHIBICION DE DOCUMENTOS.}

Tiene por objeto obligar a una de las partes o a terceros a exhibir los documentos que tienen en su poder. Puede presentarse el caso de que el documento que interesa presentarlo al juez no se encuentra en poder 
del interesado sino del contrario o de terceras personas y en este caso hay que recurrir a la exhibición, como único medio de lograr este objetivo.

Se puede distinguir entre presentar y exhibir documentos. Como sa desprende de lo dicho, exhibir es cuando se hace la presentación a pedido de otra persona, presentación cuando se hace por propia iniciativa

Personas obligadas.-Arts. 442 - 443. - Según estos preceptos legales se puede señalar las siguientes reglas respecto de la obligación de exhibir: 1) Quien es parte en el juicio está obligado a exhibir a pedido de parte con la condición de que tenga el documento en su poder.- 2) Los terceros están obligados en estas circunstancias: a) que el documento pertenezca a alguno de los litigantes; $y$ b) que a pesar de no pertenecer a los litigantes, consientan con la exhibición, no se opongan a ella.

Estudiando el caso de que se trata de litigantes, es obvio que esté obligado a proporcionar la prueba que se le solicita, como una lógica consecuencia de su situación de litigante. Fero esta situación está vinculaaja al hecho de que efectivamente tenga el documento en su poder, pues nadie puede ser obligado a lo imposible. Esto supone que el solicitante de la exhibición debe afirmar que el documento se encuentra en poder de la contraria. Este requisito es muy de tomarse en consideración, pues con alguna frecuencia se observa que un litigante pida al contrario que exhiba el documento que el primero, dentro del juicio, niega que exista.

Consecuentemente, la oposición que el litigante formule contra la exhibición solicitada puede tener un solo fundamento legal, no tener el documento en su poder.

Respecio a los terceros se puede también considerar separadamente los dos casos: 1) si se trata de documentos pertenecientes a uno de los litigantes están obligados a exhibir por la misma razón anterior. Si no fuera así y para burlar la obligación de exhibir, sería suficiente que entregara el documento a un tercero.

Es evidente que esta exhibición puede sin embargo no obligar a la desposesión del documento desde que es posible realizarla mediante copia fotostática (1).

En el segundo supuesto, esto es cuando el documento no pertené̃e a ninquna de las partes, fste puede a no voluntariamente, exhibirlo, pues no existen las razones que hemos dado para justificar la obligatoriedad de la exhibición. - Esta voluntad debe manifestarse dentro del plazo del tercer día (art. 443). - No es pues preciso que se dé razón alguna, sino que basta el hecho de la oportuna negativa u oposición para que la exhi. bición no proceda.

Actuación de la exhibición.- 1) Oportunidad: Procede como prueba instrumental, en cualquier momento del juicio. Al hacer el pedido, debe obligatoriamente darse la idea más clara del documento cuya exhibición se solicita o acompañarse copia simple del mismo (art. 444, 2 da. parte) o, para la debida aplicación de los apremios, si llegara el caso.

(1) Romero - Ob. cit. T. II -- pág. 642. 
2) El Juzgado ordena la exhibición para dentro del tercer día.- 3) Pueden presentarse tres disyuntivas: $\nexists_{x}$ ) El obligado, sea parte o no, exhibe el documento. Esta exhibición puede hacerse de diferentes maneras según se trate de documento público o privado. En el primer caso, si se trata de documento público, se cumple con la exhibición "dando razón de la oficina en que existe el original" (art. 444). En este caso al pedirse la exhibición debe afirmarse la pérdida del original y la existencia de la copia en poder de la persona a quién se exige la exhibición.

En el segundo caso, si se trata de documento privado la exhibición debe realizorse según estas reglas: a) de cualquier documento privado poniénciolo a disposición del Juez (art. 444) esto es, presentando el documento o su copia fotostática. Esto no impide que de presentarse el original, se plieda retirarlo de inmediato, solicitando que se devuelva, dejando copia certificada en autos. - b) De libros de contabilidad, correspondencia, acta u otros análogos (art. 445) poniéndose copia certificada de los asientos correspondientes. Esta diligencia se puede realizar a voluntad del obligado, en su propio domicilio u oficina o en el local del juzgado. - La exhibición de una contabilidad íntegra no procede sino en los casos de quiebra, liquidación o de cualquier otro juicio de carácter universal. En otro caso, la prueba carecería del requisito de la pertinencia.

B).-El obligado se opone a la exhibición. En este caso, la oposición esta sujeta a estas reglas: 1) La oposición al mandato de exhibición debe formularse dentro del tercer día.-2) Se sustancia como incidente.- 3) Se sustancia en cuerda separada sin interrumpir la secuela de lo principal (art. 446). El auto que resuelve la oposición, que por su naturaleza es un auto que resuelve incidente debe ser apelable en doble efecto en todos los casos. Sin embargo la autorizada opinión del Dr. J. G. Romero (1) hace una distir.ción: procede en un solo efecto si la alzada la interpone el que es parte en el juicio; y si es un tercero, procede en doble efecto según el art. 1099. - No constituye un incidente la oposición del tercero a la exhibición de documento que no pertenece $\alpha$ los litigantes.

C). -El obligado no se opone ni tampoco cumple con verificar la exhibición. Puede esto ocurrir también denegada la oposición. En este caso deberá ser apercibido para que cumpla con esta obligación. - El apercibimiento varia según se trate de que el obligado sea parte en el juicio a tercero. - Si es parte, el apercibimiento es tener por verdadera la copia que hubiese presentado la otra parte o exacta las afirmaciones que hizo sobre el contenido del documento. (Art. 447) y por excepción, si esos apercibimientos son inapelables, el apremio de detención. Es claro que los dos primeros apremios son facultivos y excluyentes entre sí. El tercero sólo procede cuando no se tiene conocimiento ni se puede precisar siquierc el contenido ciel documento.

Si se trata de persona extraña al juicio, el apercibimiento será siem-

(1) Romero - Ob. cit. T. II - póg. 647. 
pre detención.

En todo caso, en aplicación de la regla general debe indicarse precisamente el apercibimiento que se solicita y el que se decreta.

\section{PRUEBA PERICIAL.}

Consiste en la aportación al Juez de la opinión de personas expertas sobre la materia controvertida.

En general, perito es la persona que ha adquirido conocimientos especiales sobre determinaba materia (1). Desde el punto de vista del Derecho Procesal, es la persona que proporciona al Juez los conocimientos que no se le puede exigir a éste sobre las cuestiones materia de la controversia. Estas cuestiones deben referirse a los hechos. También el peritaje se refiere algunas veces a las personas como sucede entre nosotros con el procedimiento sobre interdicción de incapaces, o en los casos de emancipación.

Su razón de ser está en la evidencia de que el Juez no puede poseer todos los conocimientos científicos que requiere la apreciación de las diversas cuestiones que se plantean en los litigios. Para suplir esto se recurre a los expertos en la materia, que ilustran al Juez sobre el particular. Este asesoramiento constituye la prueba pericial.

Por esto es que algunos autores, como Carnelutti, (2) no la han considerado una prueba en sí, sino un medio para obtener una prueba. La prueba es el hecho, (3) los peritos lo aprecian y explican.

Para precisar mejor el concepto de la prueba pericial es conveniente distinguirla de la inspección ocular, de la testimonial y de la prueba arbitral.

Se diferencia de la primera por cuanto la inspección ocular es la constatación que hace el juez, por sí mismo, de la existencia de los hechox que se debaten.

En cambio, los peritos determinan las causas $y$ efectos de los hechos (4) y las razones de orden técnico que pueden pasar desaparcibidas a primera vista. Así se puede comprobar de visu la rajadura que presenta un muro, pero no la causa de la misma, la inminencia de que el muro se do. rumbe; esto sería materia de la prueba pericial.

También se distingue de la prueba testimonial en que: 1) el testigo declara sobre hechos que conoció en el juicio (1); el perito de hecho existente en el momento que realiza la operación. - 2) El testigo es examinado; : 1 perito examina (2)._- 3) El testigo relata objetivamente los hechos; el perito tiene que hacer apreciaciones.- 4) El testigo y el perito tienen diferente función; pues el primero proporciona al Juez el conocimiento de los hechos; el segundo ilustra al Juez sobre los hechos comprobados.

(1) Roworo - Ob. cit. T. II-pág. 450

(2) I (2) - Carnolutti - Sistema No 209.

(1) Alsina - Ob. cit. T. II - pág. 351.

(4) Alsing - Ob. cit. T. II - pág. 349.

(5) Alsina - Ob. cit. T. II - pág. 347. 
Se diferencia también el perito del árbitro por cuanto este último decide la controversia; en cambio el dictamen pericial debe ser apreciado según las reglas de la crítica.

Actuación.-(Ârts. $491-494) .-$ a) En cuanto a la oportunidad de su ofrecimiento sobre el particular el art. 491 indicx que, puede ofrecerse sobre puntos que exijan conocimientos especiales de algunas ciencia - arte; esto es que procede siempre que se considere conveniente proporcicriar al Juez un conocimiento especial sobre los hechos controvertidos. En cuanto a la oportunidad del ofrecimiento puede hacerse de oficio o a pedido de parte.

Sólo en el primer supuesto está fuera de los términos procesales, pues no tiene el carácter de prueba privilegiada.

b) Respecto a la forma del ofrecimiento es evidente que debe precisarse el objeto del peritaje (art. 493) con la mayor claridad a fin de que el Juez pueda también ordenarlo con toda precisión.

c) Al decretarse la prueba el Juez resuelve: 1) sobre el objeto de la misma (art. 493). - 2) Nombra uno o dos peritos. En cuanto a la designación de los peritos los sistemas varian dando algunas legislaciones esta facultad a las partes $y$ otras al Juez y otras a las partes y al Juez conjuntamente. Segúiz nuestro sistema el nombramiento, de los peritos corresponde hacerlo -l juzgado. - Respecto al número se deja acertadamente a la decisión del Tuez para que teniendo en consideración la naturaleza del peritaje por realizarse decida sobre el número de los peritos. En algunas legislaciones, especialmente europeas, se establece que el número de los peritos debe ser impar. Sin embargo de que esto se hace con el fin de evitar que se prociuzcan empates, lo cierto es que por lo menos, en casos muy complicados, en que el asunto puede tener diversas soluciones, no elimina la posibilidad de que haya que nombrar peritos dirimentes. Si se trata de sólo asesorar al Juez en alguna diligencia bastará nombrar uno; en los casos de valorizaciones, etc. se acostumbra nombrar dos peritos.

Se pueden señalar estas etapas en la actuación de la prueba pericia: 1) El perito debe aceptar el cargo. Esto se puede manifentar exprosamente o implí itamente mediante la prestación del juramento.- 2) El periti de-lara bajo juramento que despeñará el cargo con fidelidad (art. 494). Do sie jur: mento, que debe ser previo y es esencial, se sienta acta. 3) El peritaje pueje practicarse en presencia del Juez o fuera de esta. En primer caso el Juez señalará el día, hora y lugar. Los interesados pueden concurrir $\alpha$ esa diligencia y hacer las observaciones que estimen oportunas (art. 495), pero no tomarán parte en las deliberaciones de los peritos. En este corso el perito puede: $\alpha$ ) presentar su dictamen verbalmente en esa diligencia lo que cor:stará en el acta respectiva.- b) Pedir prórroga para presentarlo después. En este caso el Juez señalará plazo para la presentación del dictamen teniendo en cuenta la naturaleza y dificultad de la operación por practicarse. Entonces el informe se practicará por escrito. Si son varios los peritos y estớn de acuerdo pueden emitir un dictamen en común. En cualquiera de los casos, el dictamen debe ser motivado (art. 497). Fs claro que este requisito tiene por objeto evitar los dictámenes arbitrarios y que 
puedan apreciar por razones de orden científico o técnico en que se fundor $\alpha$ fin de que sean apreciadas por las partes y puedan ejercitar el derecho de,. tacha $y$ el juez pueda también apreciarlo debidamente, al sentenciar.49) Si las paries no están de acuerdo es potestivo del juez nombrar un dirimente (art. 499). - 5) El peritaje se pone en conocimiento de los interesados y dentro del tercero día según el art. 498, pueden hacer las observaciones que juzguen oportunas, es decir, solicitar que se aclare, se explique o se amplie el dictamen. - Pueden suceder dos circunstancias: 1) Que el juzgado acepte las observaciones en cuyo caso puede mandar que se "aclare, se explique o se amplíe - el dictamen - mandar que se rehaga, o designar otros peritos". Es de notar que todos estos actos son potestativos del Juez. - 2) Que el juez no acceda a las observaciones. - La razón de esto es que tiene carácter meramente ilustrativo para el juez y si él estima suficiente el dictamen no tiene por qué admitir las observaciones que las partes. haya:i formulado contra él (2a. parte art. 498).

Por la misma razón las explicaciones, ampliaciones y rectificaciones pueden ordenarse también de oficio.

La prueba pericial se puede efectuar ante un juez comisionado siempre que no pueda efectuarse en el mismo lugar del juicio, procede esta forma de actuarse el peritaje.-. En general las atribuciones del comisionado son iguales a las del Juez originario.

Sanciones.-Art. 500.-El perito puede no aceptar el cargo; pero si: lo acepta queda obligado a presentar su operación dentro del término que se le haya señalado bajo severas sanciones.- Estos son: $1^{\circ}$ las de apercibimiento; $2^{\circ}$ multa; $3^{\circ}$ pago de los perjuicios; $y 4^{\circ}$ subrogación. Estas últimas son aplicadas después del apercibimiento según el ciierio del Juez.

Gasios.-Art. 503. - Siguiendo la reg!a general los honorarios de los peritos que se encuentran regulados por el Arancel de Derechos Judiciales de fecha 19 de julio de 1961, son de cargo de quien solicita la diligencia, salvo que haya sido decretada de oficio en cuyo caso los gustos son divisibles por igual entre las partes litigantes; por supuesto que todo. esto sin perjuicio de lo que se establez a sobre pago de costas.

Peritos de parte.- Art. 503. - "Las partes tienen la facultad de presentar en cualquier estado del juicio informes con firmas legalizadas emitidos por personas competentes sobre los punios que son materia de la pritba pericial".

Es la única forma de refutar los dictámenes periciales hechos por peritos nombrados por el juzgado. Estos informes se presentan con firmas legalizadas ante notario. - Sus autores no están sujetos a ninguna de las obligaciones y garantías que la ley impone para la otra forma de perilaje. Ello constituye una especial forma de prueba literal, no instrumental $Y$ por lo mismo no cabe su reconocimiento.

Valor probatorio.-Arts. 501 - 504. - El juez asigna valor probatorio al peritaje, según las reglas de la crítica, esto es las reglas lógicas y de sentido común; no obliga la decisión del juez ni hace prueba plena en 
ningún caso lo cual se justifica ampliamente porque en caso contrario el perito sería el juez que decide la controversia.

\section{PAUEBA TESTIMONLAL.}

Está constituída por la declaración jurada de la persona que no es parte en el juicio y que declara a pelición de uno de los litigantes sobre los hechos que ha presenciado, $\mathrm{u}$ oído y que son materia de la controversia.

Anteriormente se ha establecido las distinciones entre esta prueba y la de confesión, así como también de ia prueba pericial y a ellas nos remitimos.

De la definición que precede se desprende: a) Que se trata de una cieclaración de tercera persona, esto es que los propios litigantes, corio es cbvio, no pueden ser testigos en su propia causa, cun sus parientes, a los más cercancs, les alcanza la prohibición o por lo menos algunos restricciones para testificar como se explica más adelante, al tralar de los prohibidos e impedidos de declarar. - b) Esta declaración debe ser prestada bajo juramento: sin embargo, las declaraciones de los menores de 18 cinos se prestar sin este requisito; c) Deben prestarse dentro del procedimiento: civil a petición de parte. Esto es que no puede actuarse de oficio. Esta es ura de las probanzas que el Juez no puede decretar por propia iniziutiva. La yazón es doble: 1) La dificultad del juez para conocer a las personas que puedan saber los hechos que se controvierten; 2) El principio de la regulación de la prueba lestimonial, que señala restricciones para su cctuación.-- d) Debe tratarse de personas que conocen los hechos controvertidos. Este conocimiento puede ser de primer gredo; cuando el declarante ha presenciado los hechos $y$ le constan personalmente, entonces se llama testigo presencial; o puede ser de segundo grado, cuancio ha conacicio los hechos por medio de otras personas $y$ es entonces testigo de oídas, cuya declaración tiene mucho menor valor y mérito que la anterior.

Importancia.-La prueba es importante porque no todos los hechos, sino al contrario, sólo una ínfima parte de ellos se conservan en documentos - fueden comprobarse de visu por el Juez. En la mayoría de los casos hay que recurrir al testimonio de otras personas para acreditarlos.

Pero contra su mérito conspiran muchos elementos tanto de orden irtelectual como moral. Las condiciones de inteligencia de la persona, facilidad de percepción, memoria, su sincera fidelidad a los hechos. Por otra parte la influencia de la simpatía, de la parcialidad y demás factores que conciente o maliciosamente inciden en la declaración de las personas y que perturba la objetividad $y$ realidad de los hechos o francamente la desfiguran. - Esto último, en épocas de moral relajada es tan frecuente y el abuso que se ha hecho de testimonios falsos, ha llevado a que aparezca desde antiguo, la idea, si no de suprimirla, por la menos la de establecer la insuficiencia de su mérito en algunos casos.

Como no ha sido posible su absoluta $y$ radical proscripción por las razones antedichas, se ha procedido a lo que se llama la regulación de la prueba testimonial. Esto es, limitar su uso. Esta requlación se demues- 
tra en nuestra legiskación: a) Con la declaración de improcedencia en ciertos casos tales como cuando se trata de la acción de filiación (art. 366 C.C.) o para probar el mutuo mayor de 500 soles (art. 1585 C.C.) o en la acción de desahucio por talta de pago (art. 958 C.P.C.). - b) En la prohibición de declarar de algunas personas que desde muy antiguo se ha establecido como inhábiles de prestar testimonio por presunción de falta de imparcialidad (art. C.C.P.).- c) con la limitación del número de testigos (art. 466 C.P.P.) y, d) con la concesión al Juez, de apreciar las declaraziones según las reglas de la crítica, esto es para poder apartarse de ella si su íntima y fundada convicción la considera indigna de credibilidad (art. 450 C.P.P.). Sin embargo en el Código Procesal alemán (arts. 383 se ha adoptado el sistema de que la prueba testimonial sea admisble en todo caso, pero esto se compensa con amplísimas facultades que se otorgan al juez para apreciar su mérito $y$ asignarles el valor que viəre corresponderle. En cambio, entre nosotros esta limitación es doble y ofrece así mayor garantía, pues la prueba se regula y limita y aún la declaración de los hábiles para declarar queda sujeta al criterio judicial sobre el conocimiento de los hechos por el deponente y las circurstancias que rodean al testigo. Esta forma significa además que se ha abandonado el antiguo criterio de la prueba medida por la cual tres testigos conformes de toda conformidad hacian prueba plena, con el sistema de la pesada, en $l_{\downarrow}$ cual el número de testigos no significa nada para el mérito sino la caliciad e idoneidad de los testigos.

Clasificaciones.-Según queda enunciacio los tesitigos se pueden clasificar en: a) testigos presenciales o de primer grado; b) de referencia o de segurido grado según que hayan presenciado el evento que crtestiguan o simplemente lo conczac por referencia de otras personas.

Persona que puede ser testigo.-Art. 449. - La regla general es que toda personx es hábil para declarar si no tiene ninguina de las tachas establecidas por la ley.- De ello se desprende: 1) Que pueden decla. rar las personas de uno u otro sexo.- 2) Que la ley señala a las perso. nas que no pueden ser testigos.- Esta ley es la procesal. No basta ser persona capaz según el Código para ser testigo, sino que es preciso no estar impedido de serlo según el C.P.C. - Fste para determinadas inhabilidedes tiene en consideración la edad, la incapacidad mental o física o moral y ol grado de incapacidad.

Por otra parte toda persona no impedida está en el deber do testificar (art. 457 C.P.C.) como una contribución que se debe moral y legalmente a la recta administración de justicia. En compensación tiene el derecho de que se le abonen los perjuicios que le puede ocasionar la comparecencia.

Sin embargo existe contra esta regla general la respectiva excep. ción consignneida en el cat. 457, según la cual esta obligación no comprende ni rige en cuanto a eclesiásticos, abogados, apoderados, médicos, matro. nas, etc. sobre hechos que han tenido conocimiento en el ejercicio de su ministerio o por razón del ejercicio profesional, consagrando una vez más el principio del secreto profesional. 
Personas prohibidas de declarar.-(Arts. 452 - 453). -Debe hacerse una clasificación entre: a) personas prohibidas de declarar, crt. 452,453 y b) personas impedidas de declarar, art. 454. De las primeras el Juez no puede admitir el testimonio aunque las partes lo consientan; el testimonio de las segundas debe ser admitido y sólo no tomarse en consideración por gestión de parte $y$ resolución judicial.

Entre los primeros hay que hacer esta subclasificación: entre personas absolutamente prohibidas de declarar, y por las que debe enten. derse las que no pueden ser testigos en ningún juicio; $y$ las personas relativamente prohibidas. que son las que están impedidas de ser testigos sólc en algún determinado proceso o procesos pero no en los demás. Examinaremos a continuación estos casos $y$ el recurso que se debs hacer valer para impedir las declaraciones de quienes están comprendidos en uno y otío caso.

A) Personas absolutamente prohibidas de declarar.-Art. 450. Son las siguientes: 1) Por razón de edad, los menores de 18 años, inc. 1:Esto se debe indudablemente a las condiciones psíquicas y físicas de los menores de esa edad por ser más fáciles a la mentira y a la sugesîón (1).

Sin embargo pueden aceptarse las declaraciones de los merores de 18 años con estas condiciones: a) Si el Juez los considera con discernimiento suficiente. - b) Que las presten sin juramento.- y c) La prescripción general de que no se trate de hecho acaecido cuando tenía menos de 14 años (art. 451). A veces se exige una edad mayor por razón de que el hecho que debe testimoniarse lo requiere, como la edad de 40 años, oue establece el art. 1298 del C.P.C. para prestar declaración en el procédimiento de títulos supletorios en los que debe acretitarse posesión de 30 años.

2) Por razón de falta de razón mental: a) los interdictos por causa de enfermedad mental. Fis obvia la razón de que los enfermos mentales no pueden ser testigos. Pero debe notarse por esta misma causa que no sólo aquellos que se encuentran en estado de interdicción judicialmente declarada se encuentran impedidos de declarar, sino todos los que sufren de enfermedad mental que los priva de facultades precisas para ofrecer un testimonio digno de credibilidad.

3) Los privados del uso de la razón por embriaguez al tiempo de realizarse los hechos o en el momento de declarar (inc. 3\%). - Está justificado como en el caso anterior desde que carecen de las condiciones minimas para ser creidos. No se traia del ebrio consueiudinario que es incapaz relativo según el C.C.

4) Por imposibilidad física, o privación del sentido necesario para percibir los hechos al tiempo de verificarse éstos (inc. $4^{\circ}$ ) y los sordomudos que no saben leer ni escribir (inc. 5\%). Los primeros no pueden declarar sobre hechos que no han podido físicamente conocer como los que se perciben por el oído o la vista, si es sordo o ciego, respectivamente. Los se-

(1) I. Prioto C'astro - Ob. cit. T. I - pág 355. 
gundos, porque aunque ccnozcan los hechos no pueden expresarlos por no sciber lees ni escribir.

5) Por razón de falta de solvencia moral comprobada tales como: $a$ ) las personas indignas de fe por razón de malas costumbres o vagancia (inc. 6\%) y por lo mismo expuestas a declarar en falso. b) los condenados por falso testimonio (inc. $7^{\circ}$ ) que ya han comprobado ser capaces de declarar falseando la verdad, debiendo notar que se requiere sentencia judicial condenatoria anterior a su nueva presentación como testigo. Esta causal de probibición es distinta de la tacha que se puede formular contra un testigo que ya ha declarado, la que debe acreditarse dentro del juicio sin formarse incidente aparte $y$ que puede ocasionar una acción penal; c) los sujetos a mandamiento de prisión.

B).-Personas relativamente prokibidas de declarar.-(Art. 454) o sea que sólo están prohibidas de ser testigos en determinados juicios por razón de deberes de superior jerarquía y por impedirlo el cumplimiento de debe-.. res profesionales.

Ásí no pueden ser testigos: $\alpha$ ) por parentezco con alguna de las partes: 1) El cónyuge, ascendiente o descendiente y hermanos; ya sean legítimos o ilegítimos reconocidos, el adoptante y adoptajo de aigunas de las paries. No se puede obligar a estas personas a prestar declaraciones en contra de sus más allegados parientes, poniéndolos en la encrucijada muchas veces de mentir o de indisponerse con ellos (incs. $1^{\circ}$ y $2^{\circ}$ art. 454).-2) Los que se encuentren dentro de estos mismos grados de parentezco con el juez o actuario de la causa (inc. $4^{\circ}$ art. 452). - 3) Por deber profesional 0 de función como en los casos de los incisos $3^{\circ}$ y $4^{\circ}$ del mismo art. 452 , el abogado y personero de una de las partes.

Sin embargo, existe la excepción establecida en la 2a. parte del art. 452. Los prohibidos por rcizón de parentezco en los incisos $1^{\circ}$ y $2^{\circ}$ del art. 452. pueden ser testigos en los casos sobre edad, filiación, estado civil y cerechos de familia. F'sto está justificado por tratarsa en todos estos casos de cuestiones que los exiraños ordinariamente no conocen.

Recureos.- Los jueces no pueden admitir el testimonio de la perso. na que notoriamente estuviese comprendida en los casos de prohibición. En caso de odmitirse cabe el recurso de oposicićn a la admisión de la probanza. Es una aplicación del uso general del recurso de opcsición con el objcto de que quede sin efecto la admisión de la prueba.

Las reglas respecto a las personas impedidas de declarar. - (art. 454).--Son: 1) El juez debe admitir estos testimonios.- 2) Los impedimentos deben ser alegados y demostrados por las partes. - 3) Las declaraciones se actúan apesar de la tacha formulada contra ellas.

Especialmente los impedimentos para declarar esián fundados en la simple presunción de falta de imparcialidad del testigo; si dicha presunción no existe para la parte que lo ofrece, desaparece el inconveniente, puede ser admitida. Esto es que "la declaración de las personas impedidas de declarar (art. 454) conserva su valor en tres casos: a) si el impedimento es común a las partes litigantes. - b) cuando estas personas impedidas son preseniadas por el litigante a quien perjudica el impedimento, esto es 
que cree que el testigo no esió expuesto a la parcialidad apesar de los vínculos que le unen con la parte contraria o la parte contra la que so ofrece.- c) cuando las fartes no proponen la tacha o expresamente renuncian a la establecida en su propio beneficio (art. 456).

Personas impedidas de declarar.-Las personas impedicias de declarar son las siguientes: 1) Por razón de la vinculación o representación legal, el tutor y curcador. Así lo establece el inc. $1^{\circ}$ del art. 454 al referirse $\alpha 1$ guardador y pupilo, pues la terminología ha cambiado en el C.C. vigente Es claro que dentro del carácter de las funciones que tutores y guardadores ejercen respcto al guardado, permiten tener la presunción de la carencia de imparcialidad en que se fundan estos impedimentos. 2) Por razón de parentezco (inc. $2^{\circ}$ ), con algunas de las partes, ya sea creado por el Derecho civil o por el Derecho canćnico. Respecto al primero el parentezco debe estar dentro del $4^{\circ}$ grado de consanguinidad y $2^{\circ}$ de afinidad incluyéndose a los ilegítimos si el vínculo consta de reconocimiento o resolución judicial. En cuanto al Derecho canónico el creado por el padrinazgo respecto al compadrazgo, que no crea vínculos según el Derecho de la Iglesia.

3) Por razón de dependencia del testigo respecto al que lo ofrece. Son los casos en que el testigo ofrecido depende del que lo ofrece por razón de vinculación económica y muy especialmente por razones de vinculación laboral.

4) Por enemistad grave con la parte contra la que se ofrece el testimonio. Sólo cabe destacar que se requiere la gravedad de la enemistail para estar comprendido dentro de esta causal de impedimento.

5) Por tener en el juicio interés directo o indirecto linc. $5 \%$ ) que hace peligrar la imparcialidad. Esto es en los casos en que tenga otro juicio sobre cuestión igual o similar interesándole obtener una resolución fzvorable que pueda causar ejecutoria.

El recurso.-Para que no surian efecto las declaraciones heridas do alguna de las causales impeditivas, existe el recurso de tacha. Es este el recurso que tienen los litigantes para que se denuncie que el testigo cfrecido está impedido de declarar.

Este recurso procede: 1) Cuando sólo se trata de casos de impedimenio para declarar no de prohibición de hacerlo.--2) si el impedimento no es común a las dos partes (art. 456), 3) si no ha ofrecido al testigo la parte a la que perjudica el impedimento, tal el caso de ofrecer una parte como testigo al pariente de la otra (art. 456) y 4) en el caso del propio testigo, sólo afirmándose que ha sido sobornado (art. 459).

Oportunidad.-Arts. 460 y 461 . - Las tachas a los testigos pueden proponerse antes, durante y después de actuada la declaración a que se refiere, con la siguiente regulación: $\alpha$ ) antes de actuarse la declaración debe proponerse por escrito (art. 460). - b) en el acto de la declaración, esto es antes de que se comience a absolver el interrogatorio, verbalmente, dentro del acta de la declaración. - c) Después de aciuada la prueba (art. 461) fundándose en prueba escrita.

Efectos. - En cuanto a sus efectos, la interposición del recurso de tacha (art. 455) no impide que se actúe la declaración del testigo tachado, 
pero una vez comprobados los fundamentos de la tacha, se priva a la declaración de valor probatorio.

Sustanciación de las tachas.-(Arts. $462-455-464-463$ ). Las tachas se sustancian como incidentes según el art. 452, sin embargo deben distinguirse dos casos: a) las tachas deducidas antes o en el acto de la deciaración, se tramiton como inciciente. - b) Las deducidas después de la declaración según el art. 461, sólo mediante el trómile de "tenerla presente con citación de colitigante" (art. 461). Esta citación tiene por fin que el contrario pueda aceptar o tachar la prueba instrumental presentada. La propia declaración no puede constituir la prueba escrita en que debe apoyarse la tacha, como muy bien lo expresa el Dr. Romero (1).

Deritro del incidente de tach $\alpha$ se puede ofrecer toda clase de pruebas, pero lo lestimonial está restringida, pues no puede ofrecerse más de tres testigos para acreditar las tachas (art. 466). Las tachas de los testigos ofrecidos dentro del incidente de tacha no pueden comprobarse con prueba testimonial.

Las tachas son resueltas al sentenciar o dentro del incidente en que se han producido (art. 463). Esto significa que la tacha a los testigos ofrecidos dentro de lo principal se debe resolver necesariamente en la sentencia por constiiúr la oportunidad legal de apreciar las pruebas. Las lachas de los testigos propuestos dentro del incidente de tachas se pueden resolver dentro del incidente o al sentenciar pues, por regla general, los incidentes pendientes pueden resolverse con la sentencia.

Aciuación de la prueba testimonial. - 1) Oportunidad. - La prueba testimonial no es privilegiada, luego debe ofrecerse y actuarse dentro del término probatorio.

2) Otrecimiento.- Art. 465.- Al respecto hay dos prescripciones legales: $\alpha$ ) debe indicarse los nombres, domicilio y profesión de las personas que se ofrecen como testigos con el fin de que estén bien identificaàas al respecto de poder hacer uso de los recursos de oposición y tacha. Es claro que el domicilio está tomado acá como casa donde habita la persona y la profesión sólo se indica si el testigo la tiene, tomándose en el sentido de ocupación habitual. b).-Debe limitarse a cierto número. Art. 466. - Se ha limitado el derecho, no pudiendo ofrecerse más de seis testigos paru la comprobación de cada uno de los hechos controvertidos en el juicio $y$ tres para acreditar las tachas a los testigos. Debe notarse que si hay varios hechos controvertidos, para la comprobación de cada uno se puede ofrecer hasta el número indicado. Se ha establecido que para ello basta hacer la afirmación previa de que los testigos ofrecidos depondrán sobre hechos dentro de los límites que la ley señala. Como los interrogatorios pueden ser presentados o formulados en el mismo momento de la diligencia, esto obliga al control del número de testigos que declararan sobre un mismo hecho a fin de impedir que se exceda el número señalado, lo que no siempre es fácil.

(1) Romero - Ob. cit. T. IIl pág. 105. 
3) Ofrecida la prueba testimonial, el juzgado señalará dío y hora fara su actucrión o comisionará al juez correspondiente en czso de que, por esiar el testigo fuera del lugar del juicio, deba actuarse la diligencia por comisión. El juzgado debe ceñirse a siertas reglas en cuanto al tiempo y al lugar. En cuanto al tiempo debe mediar por lo menos dos días entre la notiticacićn del decreto de admisión de la prueba y el que señala para el examen de los testigos (art. 468, 2da. parte) para que haya el tiempo suficiente de indagar sobre la existencia de causales que puedan dar lugar a los recursos inpugna'orios.

En cuanto al lugar, en principio general, los testimonios deben actuarse en el lozal del juzgado, pero hay las siguientes excepciones: a) For enfermedad, ancianiajad u otros motivos anólogos, según apreciación del juez -art. 483- en cuyos casos la declaración se tomará en el domicilio del testigo constituyéndose allí el juzgado y pudiendo concurrir las partes y sus defensores. - b) Por dignidad pudiendo en razón de los cargos que ocupan, el Presidente de la Fiepública, el Arzobispo y los Obispos en sus respectivas Diocesis, pueden prestar declaración en sus domicilios o en el local de su despacho, a su voluntad (art. 434).

4) Pueden presentcrse tres cases en la actuación de esta prueba: a) que el testigo concurra, encuentre el pliego o persona que deba interrogarlo.- b) que concurra y no encuentre ni pliego ni persona que lo interroge.- c) que no conctrra. - Los examinaremos separadamen!e.

a) Concurrencia del testigo.- Art. 467.- En el primer supuesto. esto es que encuentre el interrogatorio o la persona que pueda interrogarle debe indicarse varias etapas: 1) Interrogatorio. La prueba testimonial supone para su aciuación interrogatorios que pueden ser verbales o escritos. La última forma es la usual. Este pliego puede ser abierto o cerrado y se puede presentar en cualquier momento hasta en el acto de la declaración. Los interrogatorios verbales pueden ser hechos por las partes, sus apoderados, a falta de la parte, sus abogados, estos sin necesidad de que esten presentes las partes a quienes patrocinan. Cada prequnta debe contener un solo hecho (ari. 475).

2) Juramento.-Art. 469.-Antes de la declaración el juez tomará juramento al tesigo, en la forma que lo establece el art. 469. La fórmulá no acimite la declaración testimonial de los ateos o de los que no creen en Dios. Cualquier otra fórmula sería ociosa o sin ninquna importancia, pues una cosa es poner a Dios como testigo sancionador de su dicho, y otra muy distinta ponerse a uno mismo como testigo y juez de su conducta jurando por su honor, por ejemplo.

3) Se puede actuar el testimonio sólo ante el actuario de la causa o secretrrio del juzgado que interviene en el pleito (art. 470), solo si ambas partes lo consienten. Esta regla excepcional se ha convertido en general por razón del número de integral que hacen imponerse a intervención personal del juez es...

4). - En la actuación de los testigos se siguen las reglas que ya se han estudiado y que son aplicables también a la confesión. Se puede resunir tratando de las partes y el juez. - De las obligaciones del testigo, 
las principales son las de los artículos 472 y 473 según los cuales el teztigo responderá por sí mismo de palabra sin valerse de ningún borrador 0 respuesta; pero excepcionalmente puede consultar libros, cuentas o papeles. Además deberá contestar con precisión las preguntas que se hagan aunque puede añadir todas les explicaciones que estime oportunas. - Las faculiades de las partes según el Art. 474, son las de interrogar al testigo, ya sea propio o de la contraria, formulando respectivamente amplia ción del iriterrogatorio o preguntas, ya sean hechas verbales o escrilas.- El juez iiene una doble facultad: rechazar las preguntas impertinentes (art. 476) y hacer al testigo las preguntas que sea conveniente para aclarar o dar razón de su cicho. La prueba testimonial no puede actuarse de oficio. Pero cabe que el juzgado haga al testigo pregunias ampliaiorias.

B) Falla de pliego e inconcurrencia de las partes.-(Art. 482). Es la otra eventualidad que puede presentarse. Esto es que concurra el testigo y no pueda declarar por no haberse presentado el interrogatorio, ni estar presente la parte que ha pedido la diligencia a fin de hacer verbalmente, las preguntas. Entonces procede asentar un acta en la que conste el hecho, firmada por el testigo compareciente y la parte contra la que se ofreció la probanza. Con este requisito previo se puede pedir que se tenga por abandonada la prueba. Esta deserción de la prueba constituye la sanción para el caso de omisión.

C) Inconcurrencia del testigo. - En este caso debe volver a citársele bajo apercibimiento de ser conducido por la fuerza pública. Se hace electivo el apercibimiento si insiste en su inconcurrencia a pedido de parte, por medio de la policía judicial. En la práctica es muy raro el empleo de este apremio, ya que fácilmente se produce una predisposición desventajosa haría la parte que lo emplea.

Áctuaciones especiales. - Por comisión (arts. 482 y 483) procede sólo cuando el testigo se encuentra a una distancia de 15 kilómetros del lugar donde se solicita. Para ello quien solicita la prueba debe acompañar el pliego interrogatorio ya sea en pliego abierto o cerrado o designar peisona que haga las interrogaciones. Todos estos son requisitos previos en todos los casos para obtener que se libre exhorto. - Se aciúa en la forma ordinaria y el juez comisionado puede hacer uso de las facultades de pedir al testigo que precise sus respuestas y dictar los apremios legales establecidos para la actuación de la prueba testimonial.

Valor probatorio.-Art. 490.-El valor probatorio se aprecia según las reglas de la crítica en el capítulo relativo a prueba confesional.

\section{VII.-ALLEGATO Y CITACION PARA SENTENCIA.}

Conforme se ha expresado anteriormente el trámite de alegato sólo procede en las causas de prueba que la ley determina. Esto es que no constituye trámite de las causas de puro derecho (art. 333) y en aquellas en que hay allanamiento (art. 322). Esto es una consecuencia de lo que son los crlegatos.

Concepto.- Alegato en sentido jurídico pero lato, es la acción o efec- 
to de alegar (1) o sea exponer a favor de una persona o idea. Pero en sentido restringido constituye en Derecho procesal el escrito on el que se analizan las pruebas actuadas tanto de cargo como descargo para demostrar que han sido probados o que han sido desmentidos los hechos alegados por las partes. Por esto es que se llama alegato de bien probado.

Sin embargo, no son ajenos al alegato las glosas de los fundamentos de derecho en que se funda la controversia.

Por eso es que podemos definirlo atendiendo a su contenido y finalidad práctica, como escrito de resumen o recapitulación de lo actuado en un juicio especial, pero no refiriéndose exclusivamente a las pruebas actuadas, cuando se encuentra terminado el debate judicial y con el fin de facilitar al juez el estudio que requiere la expedición de la sentencia.

Casos on que procede. - Es claro que por su naturaleza y fin no pro. cede en los casos en que no hay controversia respecto de los hechos y por lo mismo actuación de pobranzas.

En estos casos ya los fundamentos de derecho han sido discutidos ampliamente con la réplica y la dúplica; y cuando el demandado los ha reconocido como ciertos, no procede el trámite de alegar.

Por disposición de la ley tampoco procede en las causas de prueba 'cuando la ley no lo prescribe especialmente. Así conforme a nuestra legislación sólo procede en el juicio ordinario.

Tramitación previa.-Art. 505.- Antes de mandar alegar, el Juez debe ordenar que el Secretario del Juzgado certifique sobre el vencimiento del término probatorio. Es de notarse que este decreto no se puede expedir de oficio pues se requiere la "petición verbal o escrita de cualquiera de las partes". En otras legislaciones el trámite se decreta de oficio (2) pues el Secretario debe dar cuenta del vencimiento del término.

El término probatorio puede darse por vencido por haber transcurrido con todos los cargos, esto es comprendiendo los términos: ordinaric, pronrogado, supletorio y extraordinario o de la distancia o cuando se han actuado ya todas las pruekas ofrecidas (art. 361) aunque no hubiese fenecido.

Este cómputo es una cuestión de hecho y por lo mismo debe ser efectuado por el secretario. Debe recordarse que no se trata del transcurso de los días desde la recepción a prueba hasta el momento de la certificación, sino de los días en que, dentro del probatorio, ha estado expedita y vigente la jurisdicción del Juzgado. Los días en que estuvo suspendida por apelación concedida en doble efecto, o cuando no hubo despacho (art. 274) no zorren debiendo tomarse en cuenta únicamente los días hábiles según las reglas que ya se han anotado.

Esta razón debe ser expedida previa citación a las partes, a fin de que dentro del tercer día pueda ser objetado el hecho del vencimiento. Como lo hace notar el Dr. Romero el art. 505 sólo dice "previa notificación"

(1) Encielopedia Jurídica Española T. II.

(2) Alsina - Ob. cit. T. II pág. 536. 
no "previa citación". Si se admitiera que basta la notificación no habría que esperar el término del tercer día para expedir la razón. Pero la prác. tica ha establecido que el Código se refiere a citación.

Luego se expide el decreto por el que "manda alegar por las partes por su orden, si lo tuviesen a bien". Estas pueden obtener la entrega del expediente por medio del procurador según los arts. 131 y 132.

Caracteres. - a) El alegato es facultativo. No obliga a las partes. Esto significa que el litigante puede o no absolver el trámite de alegar sin que su omisión le irrogue perjuicio alguno, salvo una desmejora en su defensa. Es indudable de que no haciendo uso del alegato se hace carecer al juez de un elemento que le facilita una visión ordenada y de conjunto de todo lo que se ha actuado. Si bien es verdad que dentro de nuestro sistema las partes pueden en cualquier momento presentar escrito con sus alegaciones. Pueden también hacer informes verbales según el art. 319 de la L. O. P. J.

b) Forma. -No tiene el alegato una forma predeterminada en la ley. Sin embargo su contenido y objetivo hace que en la práctica tenga una construcción generalmente adoptada por la que tiene la misma configuración de la sentencia a la que se anticipa. Por esto es que trata sucesivamente de la demanda, de la contestación y de las pruebas de cargo y descargo, y de ellas se saca la conclusión.

c) Orden.-Art. 506.-Corresponde alegar en primer lugar al demandante y luego al demandado pero como ya se ha expresado la omisión no da lugar al acuse de rebeldía.

d) T'érmino.-Ant. 506.-El término para alegar es de 10 días para cada parte. Este término es prorrogable por igual tiempo según el art. 176, 2da. parte y la regla reterente a la prórroga de los términos.

Tramitación.-Art. 506.- Del alegato de una parte no se corre traslado a la otra y sólo se manda agregar a los autos.

Vencido el término para alegar o cumplido el trámite, se expide, a petición de parte, el decreto de "cutos con citación para sentencia".

Decrelo de autos con citación para sentencia. - Se trata de un decreto de prevención. Significa que el juez que va $\alpha$ sentenciar, que el debate se encuentra clausuraio y que desde ese momento ya no procede la recusación del juez.

\section{VIII -RESOLUCIONES JUDICIALES.}

Se deben entender por resoluciones judiciales las decisiones del Juzgado sobre la secuela del procedimiento o sobre las cuestiones intercurrentes o sobre el mismo fondo de la controversia. Así cuanto el Juez provea dentro del proceso constituye una resolución. Pero es distinta la jerarquía de estas resoluciones.

Es evidente la importancia que ellas tienen desde que están disponiendo sobre la marcha del proceso y sobre los derechos que se debaten.

Clases. - Se pueden hacer varias clasificaciones de las resoluciones pero nas interesa la que establece nuestra legislación. 
El art. 1073 clasifica las resoluciones judiciales según su objeto en decretos, autos y sentencias.

El Código de Procedimientos Civiles define: 1) Los decretos como las resoluciones que tienen por objeto la simple tramitación del juicio sin resolver nada. Sólo sirven para procurar que el proceso avance por sus trámites legales. - 2) Los autos son las resoluciones que resuelven las cuestiones intercurrentes del proceso, esto es las excepciones y las incidencias, según el inc. $2^{\circ}$ del artículo que comentamos.-3) Las sentencias son las resoluciones que ponen fin a la instancia $\circ$ al procedimiento no contencioso (inc. $3^{\circ}$ ). Se pueden distinguir estas tres clases de resoluciones por la forma de sus suscripción. Es posible que no esté esta clasificación exenta de defectos (1) pero son términos que tienen su significación técnica y por lo mismo pueden ser adoptados.

Tiene esta clasificación gran importancia porque sobre ella se establecen las reglas para la concesión de recursos impugnatorios.

Plazo para expedir sentencia.-(art. 1079).-La Ley Oryánica del Poder Judicial señala que los jueces deben expedir sentencias en el orden establecido en el inc. $3^{\circ}$ del artículo 148 pero no indica plazo alguno para seritenciar con lo que el art. 1079 se remite el art. 507 que manda expedir sentencia dentro de los 40 días de la notificación del decreto de "autos son citación para sentencia" pues el artículo 1079 del C. de P.C. establece que el Juez de Primera Instancia expedirá sentencia "dentro del término que corresponde".

Está sancionado el retrazo en la expedición de la sentencia con los apremios de apercibimiento, multa y suspensión según la última parte del art. 148 de la L.O.P.J. Además debe tenerse presente al respecto lo establecido en el art. $90^{\circ}$ incs. e), k) y 1) y que los arts. 93 y 94 señalan los casos en los que procede el apercibimiento y la multa por haber dejado de sentenciar por negligencia, habiéndose dejado la suspensión para los casos de conducta dolosa.

Pero débese advertir que aún cuando estos preceptos se refiere expresamente a las sentencias debe aplicarse también a toda clase de sesoluciones judiziales (2).

Actualmente también se ha establecido en la L.O.P.I. que se acaba de promulgar, el procedimiento para hacer efectivas estas quejas y las sanciones en sus artículos 101 y siguientes.

Sus requisitos.-Se señalan, requisitos para toda clase de resoluciones y especialmente para las sentencias:

I. - Los requisitos para toda clase de resoluciones se pueden clasificar en requisitos de fondo y formales. Los primeros están consignados en los artículos 1074 y 1076; los segundos en el art. 1075. En el art. 1074 se consigna estos: $1^{\text {\%) }}$ que la exposición de los hechos y citas sean exactas y puntuales. Es la parte expositiva. La resolución debe fundarse en lo

\footnotetext{
(1) Romero - Ob. cit. T. III págs, 201 y sgtes.

(2) Homero - Ob. cit. T. III pág. 240.
} 
actuado $y$ en general debe ser la adecuación de las normas al caso concreto, pero la prescripción está plenamente justificada. Es una de las formas de la motivación e indica que el Juez ha sido prolijo en el estudio del expediente. - 2) Que se resuelvan todos y únicamente los puntos controvertidos en el juicio, incidente o artículo en que la resolución se contrcie. Esto se refiere a la materia contenida en la resolución. No puede pecar ni por exceso ni por defecto. Debe resolver todos y solo los puntos controvertidos. Cualquier exceso u omisión acarrea necesariamente la nulidad de la resolución. Se funda este principio en que existe implícitamente el acuerdo entre las partes de limitar la controversia a los puntos determinados $y$ este cuasi contrato de litis contesiatio, no puede ser alterado 3) Que las resoluciones se apoyen en el mérito del proceso y de la ley. Es el requisito de la motivación que constituye la parte considerativa de la resolución. Ordinariamente debe distinguirse por su logicidad e impar. cialidad. No es recomendable que se haga mención de todos los argumentos posibles; basta los principales o el principal. Una excesiva motivación perjudica la posición del Juez, entrando a un campo polémico con la parte que no le compete. No debe tampoco censurarse la ley. pues esto está fuera del papel que le conesponde. Supone que el juez investigue dentro de lo actuado respecto a los hechos: $\alpha$ ) si han sido alegados (1) y contro. vertidos. - b) Si ellos puede incidir en el resultado de la controversia.c) Si los que pueden incidir decisivamente han sido o no probados entrondo al examen de la pruebs actuada.- d) determinar si estos hechos están protegidos por el derecho positivo. Con esto pasa a la determinación de la norma aplicable fijando en primer lugar si las partes necesitan de la tutela jurídica (2). Si la merecen con la acción interpuesta, determinándose si a ésta no le falian los requisitos necesarios, haciendo la calificación de la acción interpuesta, con presendencia de la hecha por las partes.

La Ley Orgánica del Poder Judicial en el art. $3^{\circ}$ inc. d) hace hincapié en esta condición esencial de la motivación de la sentencia, pero son aplicables a toda clase de resoluciones judiciales.

Sabido es que todo juicio jurídico se resuelve en un silogismo en quo la sentencia es la expresión. Por lo tanto hay derecho a exigir que el silo. gismo aparezca claramente formulado en la sentencia que se expida.

La motivación de la sentencia es precisamente la expresión del tra. bajo realizado por el Juez para condicionar los hechos que contradictoria. mente han sido sostenidos y probados por las partes con la norma que rige la pretención y la excepción. $E_{s}$ preciso evitar que los litigantes no sepan por qué han ganado y por qué han perdido el pleito. Constituye garantía de la administración de justicia la motivación de la sentencia. Así lo establece la Constitución del Estado y también lo reproduce el mencionado inc. d) del art. $3^{\circ}$ de la nueva Ley Orgánica del Poder Judicial al mandar "la motivación de la sentencia en todas las instancias con men.

(1) Prieto Castro - Ob. eft. pág. 378.

(2) Prieto Castro - Ob. cit. pág, 68. 
ciói expresa de la ley aplicable y de los fundamentos en que se apoyan".

Se notará que el precepto es mucho más preciso y concreto que las formulaciones anteriores. Además se ha regulado este precepto en lo que se refiere a la Corte Superior en el art. 160 y a la Corte Suprema en el cort. 120.

Es evidente que el preceplo está respaldado por la doctrina y el art. 227 de la Constitución vigente. También existe tímidamente indicado entre los requisitos de las sentencias y el art. 1076 del C. de P.C. que estamos comentando.

La reforma a este respecto consiste no sólo en haberlo convertido en un expreso y terminante deber de los jueces sino en imponerlo "en todas las instancias" para solucionar los vacios en que al respecto se padría incurrir y la indicación que comprende, los "fundamentos legales y de hecho en que se apoyan".

Más aún en el art. 160 se fija la misma obligación y se reglamenta para las resoluciones de Visia o de Segunda Instancia cuando interviene el Ministerio Fiscal en esta forma: "si el fallo se dicta de acuerdo con el dictamen del fiscal podrá considerarse como su motivación", esto es que la Corte Superior en este caso podrá agregarle o no otros fundamentos a su resolución. Añade: "en caso contrario, si resuelve con lo expuesto por $\in 1$ Fiscal, será indispensable consignar la motivación pertinente".

Para la Corte Suprema se reglamenta la misma obligación en el art. 120 al decirse: "la sentencia expedida en disconformidad con el dictamer fiscal, deberá expresar los fundamentos de la discrepancia".

Esta adecuación de los hechos y de la ley debe hacerse aunque no exista ley aplicable, remitiéndose a los principios generales del Derecho según el artículo III del Título Preliminar del C.C.

4). -Que se exprese con claridad o precisión lo que se manda o decide. - Es la parte dispositiva de la sentencia. Esta regla contiene dos clases de prescripciones: $\alpha$ ) que el lenguaje que debe emplearse a fin de que exprese claramente el mandato o declaración que la sentencia debe contener, no emplee palabras equívocas o rebuscadas; $\mathrm{y}, \mathrm{b})$ que claramente, sin lugar a duda, se sepa lo que se decide $\alpha$ fin de evitar controversias en el momentc de la ejecución de la resolución. Para conseguir estos fines se emplean ya las fórmulas que tienen un significado propio, "se declara fundada o infundada" (sin lugar la demanda) o se "confirma o revoca" o "hay o no hay nulidad" según se trate de Primera o Segunda Instancia o de la Corte Suprema respectivamente, apesar de lo cual es preciso siempre cuidar la claridad de la parte dispositiva.

Ademós están los requisitos formales de las resoluciones que se presentan en las formas especiales de ser suscritas.

En las resoluciones judiciales, art. 1075, se expresarán el lugar en que se expidan en letras y sin guarismos, la fecha, cantidades, fojas que se citen y artículos de la ley que se invocan, formando práctica muy celosamente sequida hasta ahora por la que las resoluciones deberán ser escritas a mano; pero el art. 245 de la nueva Ley Orgánica establece que las resoluciones judiciales "podrán ser extendidas en escritos originales a 
máquina".

En esta forma por el art. 245 se pone en vigencia lo que establecieron los Decretos Supremos de 12 febrero y 5 de marzo de 1962 que la Corte Suprema por acuerdo de Sala Plena de 8 de noviembre del mismo año dejó sin efecto por considerar que contradecían dispositivos de la Ley Orgánica que no podían ser modificados por decretos.

Las objeciones que se oponían a tal sistema en cuanto a la garantía de inalterabilidad se salva ordenando que "el Juez pondrá su rúbrica. media firma y firma entera el caso, en cada una de las páginas de] texto a máquina".

En cuanto a la forma de suscribir las resoluciones, la 2da. parte del art. 1075 preceptúa que "el Juez rubrique los decretos, ponga media firma en los cutos, Y firma entera en las sentencias; el escribano, hoy secretcrio de juzgado, con media firma los decretos y los autos y con firma entera la sentencia. En las Cortes las sentencias serán suscritas con media firma y rubricados los cutos y decretos; que autorizará el Secretcrio de Corte en la misma forma que los secretarios de juzgado. Esto significa que la rúbrica es el rasgo sin nombre alguno, la media firma equivale a sólo el apellido y la firma entera, nombre, apellido y rúbrica. De esta manera resulta que se puede conocer la clasificación de las resoluciones por la forma cómo han sido suscritas sin perjuicio de establecerse el error de la calificación.

II.--Los requisitos especiales de la sentencia están consignados en el art. 1076 que complementando el art. 1074 señala las tres partes que se pueden distinguir en una sentencia: la expositiva, la considerativa y la resolutiva.

Anteriormente se ha hecho mención al contenido de cada una de estas partes. La primera parte o sea la expositiva es la que tradicionalmente constituye los resultandos. En ella se expresa que resulta de autos: a) la expresión de la demanda y de la contestación, resumiendo así los límites de la controversia. - b) la tramitación del proceso. Esta última parte se puede hacer y se hace en forma suscinta las más de las veres declarando escuetamente que se ha seguido el juicio por sus debidos trámites, pero significa que el Juez ha compulsado el procedimiento.

Este resguardo del procedimiento se ha establecido por el art. 90 inc. j) y art. 92 de la Ley Orgánica bajo diversas sanciones.

El Título L.O. del P. Judicial que se dedica a tratar de la responsabilidad judicial es sin duda uno de los más importantes por su afán de evitar la posibilidad de infringir el deber de vigilar el orden del procedimiento, que se coloca bajo la responsabilidad de los jueces, de tal manera que si al sustanciar un procedimiento y no obstante la reclamación de parte, contrariando las forma del procedimiento y la reclamación, se incurre en omisiones originando la insubsistencia que declare el superior, los jueces incurrirán en responsabilidad disciplinaria según el art. 92 de la Ley Orgánica. Las sanciores disciplinarias a aplicarse son: el apercibimiento, la multa de 1,000 a 10,000 soles, suspensión, separación y destitución. Pero en el caso en que el error en la tramitación que haya dado lugar a la insubsistencia se deba 
a negligencia se aplicará el apercibimiento; y cuando se hay $\alpha$ incurrido en negligencia inexcusable o se le haya apercibido dos veces dentro del mismo año judicial, procede la multa. La aplicación de las demás clases de sanciones supone el dolo.

En esta forma la perjudicial insubsistencia que se produzca por negligencia del Juez apesar de la gestión de la parte para evitarla, no quedarán impunes, lo que indudablemente obliga a dar una mejor atención a los artículos de nulidad que se promuevan.

La segunda parte de la sentencia contiene los considerandos que comprende la motivación de la sentencia. Ya se ha indicado, siguiendo al tratadista Prieto Castro, las etapas que puede comprender esta parte do la sentencia.

En la última parte del art. 1076 se establece el deber de fundamentar la apreciación que haga de los documentos periciales y de la prueba del testimonio. Esto se justifica por cuanto se ha dejado al criterio judicial la apreciación de sus respectivos méritos. No se trata de una apreciación arbitraria, sino que debe ser razonada y el razonamiento debe constar expresamente.

La tercera parte es la parte resolutiva o sea el fallo sobre la cual también se ha hecho anteriormente algunas apreciaciones.

Las sentencias deben declarar el derecho controyertido condenan. do o absolviendo al demandado en todo en parte. - Tanto la una como la otra deben ser expres $\alpha$ y clara. Debe notarse que la conden $\alpha$ debe ser total o parcial. Otras formas de condena también pueden producirse como aquellas que se hacen con reserva de liquidación (1). Esta liquidación posterior a la sentencia puede hacerse o bien según las bases señaladas por éstc o remitiéndose a una fijación posterior por peritos.

Como consecuencia de la sentencia completamente condenatoria viene la condena en costas según el art. 1074 que se comentará al tratar en particular de las costas.

Efectos de la sentencia - arts. 1078 y $1080-83-84-$

La expedición en general de las resoluciones producen dos clases de efectos: 1) alinente $\alpha$ su intangibilidad y otro, 2) referente $\alpha$ su constitución como una cosa juzgada.

En cuanto a la intangibilidad de las resoluciones, el artículo 1078 prescribe que el juez no puede alterar los decretos consentidos. Tampoco puede alterar los autos y sentencias después de notificados a las partes. El precepto se funda en que con la expedición de la resolución, la intervención del juez ha concluído y además que no puede hacerse cambios que signifiquen vacilación en el juzgamiento e indecisión para las partes.

Sin embargo la regla no es absoluta. La segunda parte del mismo art. i078 permite pedir "por escrito o verbalmente, dentro del día posterior

(1) Prieto Castro - Ob. Cit. pág, 332. 
a la notificación, corregir cualquier error material o numérico, aclarar algún concepto obscuro y suplir cualquier omisión en que se haya incurido. respecto o acerca de los puntos discutidos". Debe notarse la caliciad exigida al recurso, esto es que se refiera únicamente a cuestiones de orcien. material y no afecte el criterio según el cual se ha dictado la resolución. No cabe la modificación de lo que sustancialmente manda o decide. Sólo es admisible para corregir enores numéricos, cálculos, la indicación de tolios. la aclaración de conceptos obscuros o también el complemento de la resolución que haya omitido pronunciarse sobre alguno de los puntos controvertidos.

En cuanto a la tramitación de este recurso el mismo art. 1078 pres. cribe que debe resolverse sin trámite alguno lo que justifica la calidad de la cuestión propuesta. Además se señala plazo para resolverla fijando. "el díu siguiente al de la petición".

En cuanto al otro efecto de la sentencia, es el que constituye la cosa juzgada. Para la mejor apreciación de las cuestiones legales sobre. la materia (arts. 1080 - 1083 - 1084) es preciso recordar la diferencia entre la cosa juzgada formal y la cosa juzgada material. La primera es la que adquiere una sentencia cuando no puede ser impugnada en la misma vía en que se ha expedida. Es una consecuencia necesaría de la utìidad del proceso judicial y tiene el carácter de preclusiva dentro del juicio en que se expide definitivamente, de tal manera que deja expedita la vía de la ejecución de la sentencia. Pero ella puede ser contradicha dentro de una vía. ciistinta y más amplia. Así entre nosotros las sentencias en general expe. didas en procedimientos menos extensos que los del juicio ordinario o en: procedimiento no contenciosos, pueden ser materia de revisión en vía distinta y más lata, esto es en juicio ordinario (art. 1083).

Esta contradicción debe interponerse dentro de los 6 meses de expedida. la sentencia de que se trata por que sino se convierte en cosa juzgada.

En cambio, la cosa juzgada material es la que produce la inmutabilidad definitiva de la sentencia. Se funda no como la anterior, en la utilidad del procedimiento sino en la necesidad de que los conflictos tengan un fin impuesto por la autoridad del Estado, en garantía del orden jurídiro. Ello impide que el conflicto se reabra de tal manera que ni las partes ni los que de ellas derivan su derecho puedan volver a plantearlo, ni los jueces puedan admitir una nueva discusión, menos nueva decisión, sobre lo que ha sido resuelto. - Ella constituye una resolución de lai clase que no solamente es una ejecutoria, algo que debe cumplirse, sino que es una reso. lución que además de ser cumplida se tiene en forma decisiva como la expresión de la voluntad legal sobre el particular, sin que haya poder que pueda desconocerla, sin excepción, dentro del campo del Derecho Civil.

El art. 1080 señala los casos en que queda ejecutoriada la sentencia en juicio ordinario. Son los siguientes: a) por no haberse interpuesto los. recursos que permite la ley. Para esto debe solictarse verbalmente o por escrito que los secretarios de juzgados certifiquen con citación de las partes, no haberse interpuesto recurso impugnatorio contra la sentencia, (art. 1081). El juzgado por el mérito de la certificación declarará ejecutoriada la sen- 
tencia. Desảe este momento procede su ejecución. - 2) Por desistimiento, abandono o deserción del recurso interpuesto, desde que en estos casos se produce el efecto de dejar ejecutoriada la resolución contra la que se interponía el recurso (art. 279). - 3) Por haberse fallordo la causa en última instancia o no poseer la ley otro recurso. Es obvio que aceptada las instancias la sentencia de la última, tiene que quedar firme.

$E_{s}$ de notarse que en esta forma quedan ejecutoriadas no sólo las sentencias, sino toda clase de resoluciones judiciales. Las circunstancias que se indican en los tres incisos del art. 1080 deben referirse sólo al juicio crdinario, pues no solamenie se produce entonces el efecto de que quedan ejcutoriadas las sentencias, sino que ellas, produce los efectos de la cosa juzgada.

En los casos del artículo 1083, como ya se ha indicado, se producen únicamente ejecutorias, pues las sentencias de los juicios a que se refiere pueden ser contradichas en la vía ordinaria. En cambio los que ponen fin al juicio crdinario por su amplitud, producen la presunción de la no existencia del error en el juzgador. Por el mismo razonamiento se puede con. tradecir algunas sentencias expedidas con tramitación menos extensa. Puecien contradecirse las sentencias recaídas en juicio ejecutivo, en los inter. dict:os, en los juicios de desahucio con la reserva establecida en el art. 973, esto es en el caso de declarar fundada la demanda no se produce la reposición en la locación, sino la indemnización de los daños y perjuicios; en el de alimentos, pérdida de la patria potestad, remoción, excusa y renuncia de guardadores y las resoluciones que ponen fin a los procedimientos no contenciosos de declaración de heredercs, apertura de testamentos cerrados y comprobación de testamentos ológrafos, guarda y posesión de bienes del ausente, adopción, inscripción y rectificación de partidas en los. Registros del Estado Civil e interdicción de incapaces. Es una enumeración iaxaliva.

El plazo para oponer la acción contradictoria es de 6 meses contados desde la notificación de la resolución a que se refiere (art. 1084).

Electos de la cosa juzgada.-Art. 1080.- Este precepto legal se refiere a "sentencias ejecutoriadas" pero más que a ejecutorias se refiere a la cosa juzgada material según lo ya expuesto.

Los efectos de la cosa juzgada material son varios, pudiendo señalarse respecto a las partes, al juez, y a terceros. Nuestra legislación procesal las reune en el artículo 1082, refiriéndose a que producen efectos irrenunciables respecto de las partes y de las que de ellas deriven sus derechos. Esta imposibilidad de reabrir debales sobre el particular es lo que constituye "la santidad de la cosa juzgada". Esto supone la triple identidad de que ya se ha tratado al referirse a la excepción de cosa juzgada. Sin embargo no elimina la posibilidad de que resulte la sentencia inoperante por prescripción según el art. 1168 del C.C.

El Juez tiene dentro de nuestro sistema un papel pasivo (1) respecto

(1) Prieto Castro - Ob. cit. pógs. 388 y 394. 
a la cosa juzgada; pues aunque no puede fallar contra lo resuelto, que haya pasado a la condición de cosa juzgada, tiene también que esperar que la parle demandada presente la respectiva excepción.

En cuanto a terceros, o sex para los que no han iniervenido en el proceso donde se produjo la cosa juzgada, esta les obliga, si continúan la personalidad jurídica de las partes, como causa-habientes o cualquier otro título que provenga de las partes, como en el caso de haber adquizido el derecho por enagenación de la parte a su favor. 